\title{
ISOENZYMATIC VARIABILITY OF CASSAVA ACCESSIONS FROM DIFFERENT REGIONS IN BRAZIL
}

\author{
Betânia Lúcia Rocha Cabral ${ }^{1,5}$;Joelson Araújo de Souza4; Akihiko Ando2; Elizabeth Ann \\ Veasey; Eloisa Maria Ramos Cardoso ${ }^{3}$ \\ ${ }^{1}$ Pós-Graduando em Genética e Melhoramento de Plantas - USP/ESALQ. \\ ${ }^{2}$ Depto.de Genética - USP/ESALQ, C.P. 83 - CEP: 13400-970 - Piracicaba, SP. \\ ${ }^{3}$ Embrapa Amazônia Oriental, C.P. 48 - CEP: 66017-970 - Belém, PA. \\ ${ }_{5}^{4}$ Conjunto Cordeiro de Farias - Alameda 5, 155 - CEP: 66830-000 - Belém, PA. \\ ${ }^{5}$ Bolsista CNPq. \\ ${ }^{*}$ Corresponding author <eaveasey@esalq.usp.br>
}

ABSTRACT: Cassava (Manihot esculenta Crantz) belongs to the Euphorbiaceae family, and is widely cultivated in Brazil. The objective of this study was to evaluate the isoenzymatic variability of 200 cassava accessions from the germplasm bank of Embrapa Amazonia Oriental. Seven groups were formed according to their origin: 1-Amazonas, 2-Amapa, 3-Bahia, 4-Para, 5-Rondonia, 6-Various, for accessions with a maximum of three individuals per place of origin, and 7 - Accessions of indefinite origin. The accessions were also evaluated as a whole. For the electrophoretic analyses, samples of young leaves were used in a $12 \%$ starch gel. Eight isoenzymatic systems were evaluated: acid phosphatase (ACP), leucine aminopeptidase (LAP), glucose-6-phosphate dehydrogenase $\left(\mathrm{G}_{6} P D H\right)$, malate dehydrogenase $(\mathrm{MDH})$, shikimate dehydrogenase (SKDH), malic enzyme (ME), glutamate dehydrogenase (GTDH) and isocitrate dehydrogenase (IDH). Analysis revealed a polymorphic locus for each system and high isoenzymatic variability among accessions. The average number of alleles per locus varied from 2.3 to 2.5 . Average observed heterozigosity varied from 0.381 to 0.615 and the diversity index varied from 0.479 to 0.559 . Genetic variability within groups was greater than among groups, suggesting a distribution pattern similar to what can be expected for natural populations of outcrossing plants.

Key words: Manihot esculenta, genetic variability, germplasm bank, isozymes

\section{VARIABILIDADE ISOENZIMÁTICA DE ACESSOS DE MANDIOCA DE DIFERENTES REGIÕES DO BRASIL}

\begin{abstract}
RESUMO: A mandioca (Manihot esculenta Crantz) pertence à família Euphorbiaceae, gênero Manihot, cultivada em todo o país. É a única do gênero utilizada na alimentação. O presente trabalho teve como objetivo o estudo da variabilidade isoenzimática de 200 acessos de mandioca obtidos junto ao banco de germoplasma da Embrapa Amazônia Oriental. Os acessos foram agrupados de acordo com o local de origem, obtendo-se desta forma sete grupos: 1-Amazonas, 2-Amapa, 3-Bahia, 4-Para, 5-Rondonia, 6-Diversos, incluindo-se neste grupo os acessos que se apresentavam em pequena quantidade por local de origem (um ou no máximo dois indivíduos), e 7- Acessos de origem desconhecida. Os acessos foram também avaliados como um todo. Para a corrida eletroforética, foram utilizadas amostras de folhas jovens em gel de amido a $12 \%$. Foram avaliados oito sistemas isoenzimáticos: glutamato desidrogenase (GTDH), fosfatase ácida (ACP), leucina aminopeptidase (LAP), isocitrato desidrogenase (IDH), xiquimato desidrogenase (SKDH), enzima málica (ME), malato desidrogenase $(\mathrm{MDH})$ e glucose-6-fosfato desidrogenase ( $\left.\mathrm{G}_{6} \mathrm{PDH}\right)$. A análise revelou um loco polimórfico por sistema. O material avaliado apresentou grande variabilidade isoenzimática. O número médio de alelos por loco variou de 2,3 a 2,5, a heterozigosidade média observada $\left(\hat{H}_{0}\right)$ variou de 0,381 a 0,615 , e o índice de diversidade de 0,479 a 0,559 . Observou-se maior variabilidade genética dentro dos grupos do que entre grupos, sugerindo um padrão de distribuição de variabilidade genética semelhante ao esperado para populações naturais de espécies alógamas.

Palavras-chave: Manihot esculenta, variabilidade genética, banco de germoplasma, isoenzimas
\end{abstract}

\section{INTRODUCTION}

In many tropical countries cassava provides up to $50 \%$ of the daily dietary caloric requirements of low income population (Campos, 1987). Rich in carbohydrates and energy, the whole plant is utilized: roots can be used for either human or animal nutrition while stems and leaves can provide protein, vitamins and minerals for animal feed. Loss of diversity caused by rapid degradation of the ecosystems, forest fires, advance of agricultural fronts, hydropower plants or even the substitution of primitive varieties by improved cultivars, point to the need for conservation of this material, particularly because cassava is now a cultivated species which no longer occurs naturally.

Germplasm banks aim to prevent genetic erosion of species and support plant breeding programs. Their basic function is to collect, preserve, characterize and 
identify accessions in duplicate, documenting and promoting exchange of plant material between research institutions (Fukuda, 1999). However, institutions which maintain germplasm banks do not always have the resources needed for evaluating and characterizing their collections.

Little investigation on cassava germplasm has been done in Brazil from the genetics viewpoint, mainly because of the lack of preliminary studies on genotype potential. Adequate characterization and documentation would enable more rational utilization of germplasm in breeding programs, making exchanging material and information easier (Fukuda et al., 1996).

The main causes limiting the use of germplasm held by the genebanks are: 1) plant breeders prefer working with more advanced material, originated from breeding programs and not with local varieties, old cultivars or wild species available in seed banks; 2 ) the majority of breeders possess their own working collections; 3 ) existing information concerning the accessions are considered by breeders inadequate or insufficient (Van Sloten, 1987).

Molecular and isozimatic markers are instrumental for the identification and characterization of accessions maintained by the cassava germplasm banks around the world [Centro Internacional de Agricultura Tropical (CIAT), Colombia; International Institute of Tropical Agriculture (IITA), Nigeria; Institut Français de Recherche Scientifique pour le Developpementen Coopération (ORSTOM), Ivory Coast; Embrapa Mandioca e Fruticultura (CNPMF), Embrapa Recursos Genéticos e Biotecnologia (CENARGEN), and Instituto Agronomico de Campinas (IAC), Brazil; etc.], assisting researchers in selecting material for breeding programs. These techniques facilitate the breeders' work, allowing them to identify more rapidly the best accessions to be used in genetic recombinations.

The technique of isozyme electrophoresis in starch gel is used as a biochemical/genetic marker in studies of numerical taxonomy, plant, animal and microorganism genetics, phylogenetic analysis, and mainly for identification and characterization of materials from germplasm collections (Alfenas, 1998; Peroni, 1998; Faraldo, 1999; Sambatti et al., 2000). Using electrophoresis technique in cassava accessions may provide important information regarding genotype variability, opening new perspectives for breeding programs. Electrophoretic evaluation of germplasm bank accessions also contributes to the identification of accessions with higher or lesser degree of genes in heterozigosity and homozigosity, enabling the increase of heterosis in materials of genetic plant breeding programs.

The aim of this work was to evaluate the genetic variability of 200 accessions of cassava from different regions of Brazil, kept at the germplasm bank of Embrapa Amazonia Oriental, through isozymatic markers.

\section{MATERIAL AND METHODS}

Two hundred cassava accessions from Embrapa Amazonia Oriental, Belém, PA, Brazil, were evaluated. The accessions were classified in seven groups according to their origin: 1-Amazonas (14 accessions); 2-Amapa (26 accessions); 3-Bahia (four accessions); 4Para (64 accessions); 5-Rondonia (five accessions); 6Various, which included accessions represented by small quantities per site of origin: two accessions from Acre, one from Santa Catarina, one from Maranhão, three from Pernambuco and two from Paraíba; and 7- Accessions of unknown origin (78 accessions). Data were obtained for each group and for all the accessions together.

From each accession, $20 \mathrm{~cm}$ cassava stems were planted in the experimental area of the Genetics Department, ESALQ/USP, Piracicaba-SP $\left(22^{\circ} 42^{\prime}\right.$ S latitude; $47^{\circ} 38^{\prime} \mathrm{W}$ longitude), with a replicate plantation at the ESALQ Experimental Station of Anhembi, approximately $60 \mathrm{~km}$ from Piracicaba. Recently expanded, young leaves were collected from approximately nine month-old plants, stored in plastic containers, ice-packed in thermic boxes, and taken to the Evolutionary Ecology and Applied Genetics Laboratory of the Genetics Department.

Approximately $0.2 \mathrm{~g}$ of each sample was macerated with four drops of extraction buffer (Scandalios, 1969) on chilled acrylic plates (24 cavities) and kept on ice throughout the extraction process. Each sample was then absorbed onto 4 by $13 \mathrm{~mm}$ wicks of Whatman filter paper \#3, which were stored in Eppendorf tubes in a freezer $\left(-80^{\circ} \mathrm{C}\right)$. Starch gel was used as a support medium prepared at a $12 \%$ concentration (Alfenas, 1998; Ferraz et al., 1994; Faraldo, 1999).

Two gel/electrode buffer systems were used: triscitrate (TC) pH 7.5 (Soltis et al., 1983) and morpholinecitrate (CM) pH 6.1 (Clayton \& Tretiak, 1972). Gels were maintained at $4^{\circ} \mathrm{C}$ during migration, with $20 \mathrm{~mA}$ constant current during the first 30 minutes. Wicks were then withdrawn from gels and the current set to constant 40 $\mathrm{mA}$. The voltage varied according to the gel/electrode buffer, from an average of $100 \mathrm{~V}$ under $40 \mathrm{~mA}$ for TC, and $190 \mathrm{~V}$ for the CM buffer. Gel running time was eight hours, when the bromophenol blue marker migration reached approximately $7 \mathrm{~cm}$.

After migration was completed, gels were cut into five, $2 \mathrm{~mm}$ thick slices. First and fifth slices were eliminated and the remaining used for coloration. The staining procedure was conducted in the dark at $37^{\circ} \mathrm{C}$ until the appearance of the isozymatic bands (20 to 40 minutes). Eight isozyme systems were used: malate dehydrogenase (MDH, EC 1.1.1.37), leucine aminopeptidase (LAP, EC 3.4.11.1), shikimate dehydrogenase (SKDH, EC 1.1.1.25), glutamate dehydrogenase (GTDH, EC1.4.1.3), malic enzyme (ME, EC1.1.1.40), glucose-6-phosphate dehydrogenase 
(G $\mathrm{GDH}_{6}$ EC 1.1.1.49), acid phosphatase (ACP, EC 3.1.3.2), and isocitrate dehydrogenase (IDH, EC 1.1.1.42).

Data from the interpretation of zymograms for each genotype of each accession were analyzed as individual groups and for the 200 accessions as a whole. The following genetic diversity indexes were obtained from the allelic frequencies: mean observed heterozigosity $\left(\hat{H_{0}}\right)$ diversity index of Weir (1990) (DI), mean number of alleles per loci $(A)$ and percentage of polymorphic loci $(\mathrm{P})$. These indexes are estimates obtained with software BIOSYS-1 (Swofford \& Selander, 1991). The diversity analysis in subdivided populations (Nei, 1973), is based on the distribution of the heterozigosity or total genetic diversity $\left(\mathrm{H}_{\mathrm{T}}\right)$, among $\left(\mathrm{D}_{\mathrm{ST}}\right)$ and within $\left(\mathrm{H}_{\mathrm{S}}\right)$ subpopulations. The Genetic Distance and Phylogenetic Analysis (DISPAN) software (Kumar et al, 1993) was used for this analysis, and each group of accessions was considered a subpopulation.

\section{RESULTS AND DISCUSSION}

\section{Isozymatic patterns}

Only one polymorphic good resolution locus was evaluated, although monomorphic loci were also observed in some systems (Figures 1 and 2). The $\mathrm{G}_{6} \mathrm{PDH}$ system, a monomeric enzyme which presents two bands in the heterozygotes, exhibited one locus (A) with two alleles $\left(A_{1}\right.$ and $\left.A_{2}\right)$ (Figure 1 ). $G_{6} P D H$ posed the most difficult interpretation: bands were not clearly separated in the heterozygote individuals; there was also a variation in the band height and intensity in the same locus, although the locus polymorphism was visible. Faraldo (1999), evaluating cassava ethnovarieties, observed two isozymatic loci: a monomeric $\mathrm{G}_{6} \mathrm{pdh}-1$ and a dimeric $\mathrm{G}_{6} \mathrm{pdh}-2$, while Silva (2000) observed one dimeric locus, with four alleles in one of the ethnovarieties, and two alleles for the others.

The analysis of the IDH enzyme produced the same results as those of Faraldo (1999), a monomeric activity with one locus (Idh-1) with two alleles (Figure 1), which differed from the two loci, one dimeric and another monomorphic, observed by Lefèvre \& Charrier (1993).

The ACP enzyme presented only one locus with two alleles $\left(A_{1}\right.$ and $\left.A_{2}\right)$ which behaved as a monomeric enzyme (Figure 1). Heterozygotes were not observed. The ACP enzyme in plants is mentioned by various authors as either dimeric or monomeric. The results obtained for this enzyme differed from those of Borsoi Filho (1995) and Faraldo (1999), who reported two monomeric loci, and by Lefèvre \& Charrier (1993a), who also observed two loci: one monomorphic and the other dimeric and polymorphic. Our results are similar to those presented by Silva (2000), who reported one monomeric locus with the heterozygotes showing two bands.

The ME enzyme presented one polymorphic and monomeric locus (Me-1), with two alleles (Figure 1).
Faraldo (1999) observed two monomeric loci. The literature mentions this enzyme with a tetrameric structure and one locus for most plants.

The SKDH system showed only one monomeric locus (Skdh-1) with four alleles (Figure 2), similar to the results observed by Lefèvre \& Charrier (1993a), Faraldo (1999), Silva (2000) and Peroni (1998). The latter author also found four bands, which were separated in two groups, $A$ and $B$, because of the inconsistency of band number 4 resolution in some individuals, which the author related to the different ages of the plants analyzed. Plants in which band number 4 was present were seven months older than the individuals that did not show this band. In a review on isozyme electrophoresis in starch gels in plants presented by Kephart (1990), the SKDH system is shown as monomeric with one to two loci, located in the cytosol and the plastids.

The LAP enzyme shows a monomeric structure, is located in the cytosol and acts on the catabolism of proteins. In the present research, a monomeric locus (Lap-1) with two alleles (Figure 2) was observed. A second locus (Lap-2) presented a dominant inheritance, and was present in only 34 individuals (17\%). A third locus, Lap-3, did not show a distinct resolution and was not analyzed.
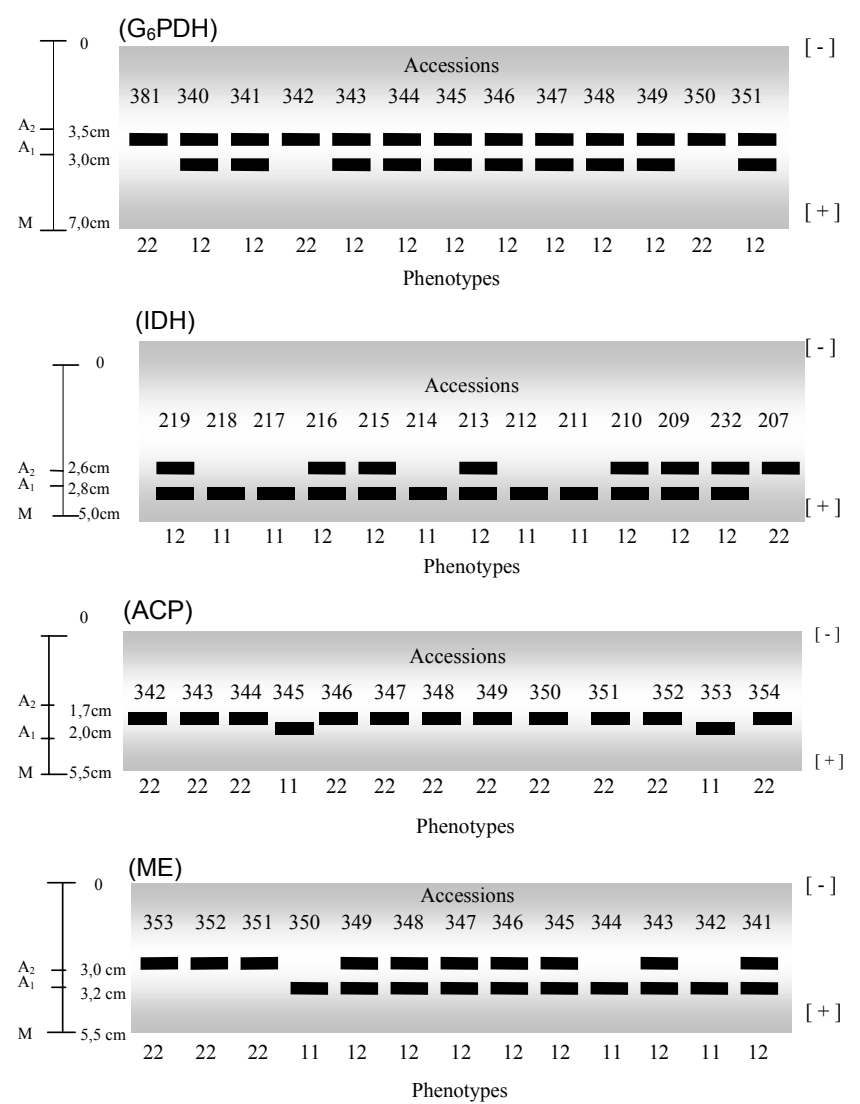

Figure 1 - Zymograms representing phenotypes of cassava accessions for the enzymes glucose-6-phosphate dehydrogenase $\left(G_{6} P D H\right)$, isocitrate dehydrogenase (IDH), acid phosphatase (ACP) and malic enzyme (ME), showing the band migration distances as well as the bromophenol blue marker migration distance (M). 
The second locus (Lap-2), represented by allele B, was also observed by Peroni (1998), Faraldo (1999) and Silva (2000). When analyzing a progeny of a cassava ethnovariety in which the male parent presented allele B, Silva (2000) observed that $55.56 \%$ of the progeny presented allele $\mathrm{B}$, and concluded that unless this allele was a nuclear gene and not of cytoplasmatic inheritance, mother plants would transmit it to all descendants.

LAP system was evaluated on leaves and roots of cassava by Borsoi Filho (1995) and showed the same pattern for both materials from six cultivars: two monomorphic bands. The author did not observe any polymorphism probably because only six cultivars were evaluated and the two bands detected were probably out of a monomeric locus $A\left(A_{1}\right.$ and $\left.A_{2}\right)$. Lefèvre \& Charrier (1993a), studying the inheritance of 17 loci in $M$. esculenta, found a locus with one to three alleles for LAP system, and considered locus $B$ as part of locus $A$.

The MDH system presented two loci, $A$ and $B$. Locus $A$ was not analysed because it was monomorphic (Figure 2). Locus $B$ was polymorphic with two bands for each individual, with three alleles $\left(\mathrm{B}_{1}, \mathrm{~B}_{2}\right.$ and $\left.\mathrm{B}_{3}\right)$. Faraldo (1999) found three loci, with two monomorphic loci and
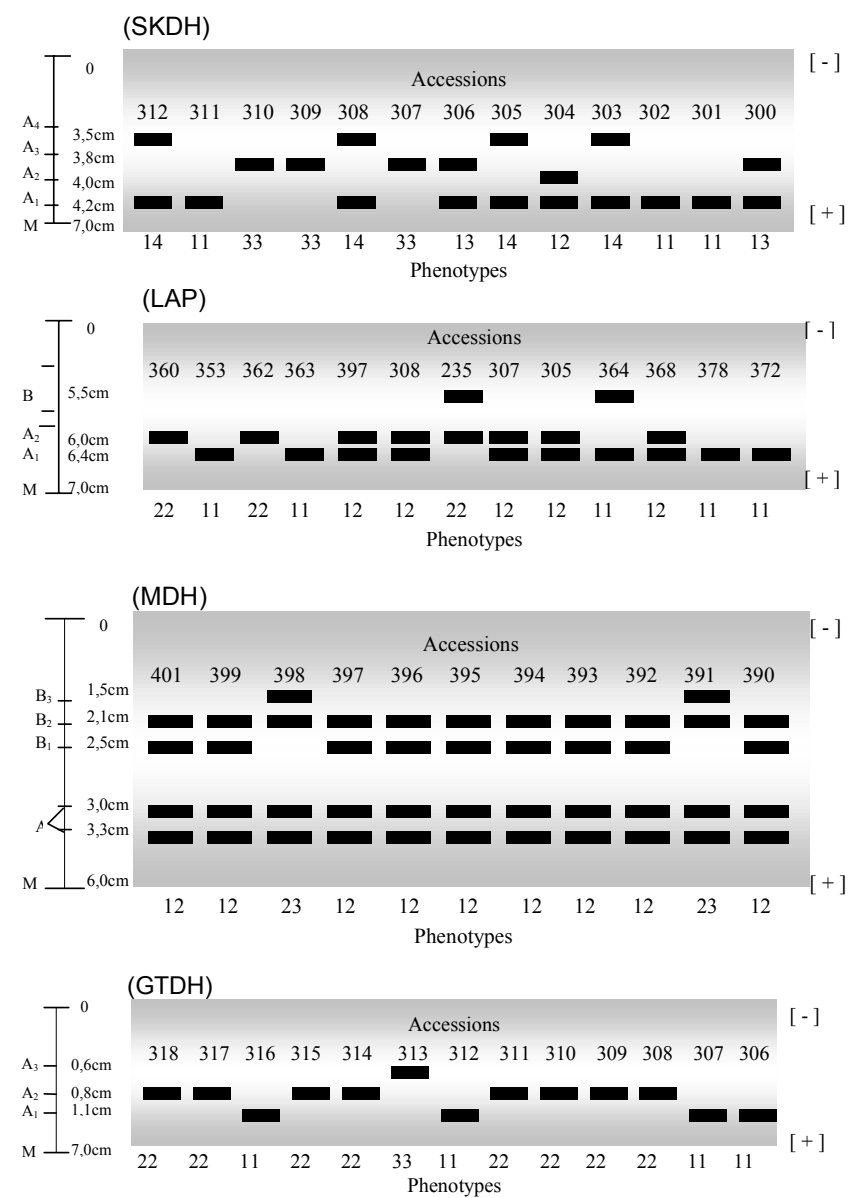

Figure 2 - Zymogram representing phenotypes of cassava accessions for the enzymes shikimate dehydrogenase (SKDH), leucine aminopeptidase (LAP), malate dehydrogenase (MDH) and glutamate dehydrogenase (GTDH), showing the band migration distances as well as the bromophenol blue marker migration distance (M). one dimeric, polymorphic locus with three bands for the heterozygotes. Lefèvre \& Charrier (1993a) observed for this system three to eight bands with three migration levels and three loci, A, B and C: two polymorphic (A and $\mathrm{B})$ and one monomorphic $(\mathrm{C})$ with two bands. Borsoi Filho (1995) found two activity zones, the first showing a monomorphic locus with three bands, the second one with more than one locus, showing enzymatic polymorphism.

The GTDH system presented a polymorphic locus with one band per individual, and three different phenotypes (Figure 2). Borsoi Filho (1995) found a single activity zone with one band per individual, which were considered homozygotes. No intermediate band was observed, probably because only six cassava cultivars were analyzed. Faraldo (1999) discarded this system, because it only presented homozygotes. The zymograms presented by the author were similar to those obtained in this work. Faraldo (1999) and Silva (2000) report that the band patterns observed in the GTDH system are preserved at any plant development stage, turning it into a functional biochemical marker for germplasm characterization.

\section{Genetic variability}

All groups showed polymorphism for the loci of the eight systems (Table 1), except for the Bahia group, which presented a fixed allele for the ACP system (allele 1 ). That could be credited to the low number of accessions - four - analyzed in this group. In group 6, alleles 3 of Gtdh-1 and 4 of Skdh-1 were absent.

Differences were not found regarding allele frequency among groups, even among accessions as different as improved cultivars and local varieties. Therefore, the most common alleles were the same for all groups. Higher frequencies were observed for some alleles in all groups and for the accessions as a whole, such as alleles 2 (Acp-1), 2 (Gtdh-1), 2 (Mdh-1), 1 (Me1 ) and 1 (Idh-1), meaning that the pattern of distribution of alleles is similar for all the populations (groups). The distribution of the frequencies between both alleles at locus Lap-1 is proportionally divided, except for the Rondonia group, in which allele 2 appears at a higher frequency than allele 1.

The number of alleles per locus varied from two to four, with four alleles for SKDH system, three for GTDH and $\mathrm{MDH}$, and two for systems ACP, G $\mathrm{PDH}, \mathrm{ME}, \mathrm{CAP}$ and IDH. The average number of alleles per locus showed low variation, from 2.3 to 2.5 (Table 2). Groups Bahia and Various showed an average number of 2.3, while the others were 2.5 alleles. Faraldo (1999) reported the number of alleles per locus for 23 cassava gardens ranging from 1.5 to 2.1 , with an average of 1.9 alleles per locus, for eleven enzymatic systems. The author considers that these values might have been influenced by the small size of some gardens (four gardens represented by only two ethnovarieties). 
Table 1 - Allelic frequencies of each isozymatic locus for the groups of cassava accessions, and for the total of the accessions.

\begin{tabular}{|c|c|c|c|c|c|c|c|c|}
\hline \multirow[t]{2}{*}{ Locus } & \multicolumn{8}{|c|}{ Group } \\
\hline & Amazonas & Amapa & Bahia & Various & Para & Rondonia & $\begin{array}{l}\text { Accessions of } \\
\text { indefinite origin }\end{array}$ & Total \\
\hline \multicolumn{9}{|l|}{ Acp-1 } \\
\hline (n) & 14 & 26 & 4 & 9 & 63 & 5 & 78 & 199 \\
\hline 1 & 0.357 & 0.192 & 0.000 & 0.222 & 0.190 & 0.200 & 0.269 & 0.231 \\
\hline 2 & 0.643 & 0.808 & 1.000 & 0.778 & 0.810 & 0.800 & 0.731 & 0.769 \\
\hline \multicolumn{9}{|l|}{ Gtdh-1 } \\
\hline (n) & 13 & 23 & 3 & 9 & 55 & 4 & 73 & 180 \\
\hline 1 & 0.077 & 0.196 & 0.333 & 0.111 & 0.291 & 0.250 & 0.329 & 0.269 \\
\hline 2 & 0.538 & 0.500 & 0.333 & 0.889 & 0.436 & 0.500 & 0.521 & 0.508 \\
\hline 3 & 0.385 & 0.304 & 0.333 & 0.000 & 0.273 & 0.250 & 0.151 & 0.222 \\
\hline \multicolumn{9}{|c|}{ G6pdh-1 } \\
\hline (n) & 14 & 25 & 4 & 9 & 64 & 4 & 78 & 198 \\
\hline 1 & 0.393 & 0.380 & 0.375 & 0.444 & 0.422 & 0.500 & 0.442 & 0.424 \\
\hline 2 & 0.607 & 0.620 & 0.625 & 0.556 & 0.578 & 0.500 & 0.558 & 0.576 \\
\hline \multicolumn{9}{|l|}{ Skdh-1 } \\
\hline (n) & 14 & 25 & 4 & 9 & 61 & 4 & 75 & 192 \\
\hline 1 & 0.393 & 0.400 & 0.375 & 0.500 & 0.344 & 0.125 & 0.307 & 0.344 \\
\hline 2 & 0.107 & 0.260 & 0.000 & 0.333 & 0.238 & 0.250 & 0.280 & 0.247 \\
\hline 3 & 0.321 & 0.280 & 0.125 & 0.167 & 0.254 & 0.500 & 0.300 & 0.279 \\
\hline 4 & 0.179 & 0.060 & 0.500 & 0.000 & 0.164 & 0.125 & 0.113 & 0.130 \\
\hline \multicolumn{9}{|l|}{ Mdh-1 } \\
\hline (n) & 14 & 25 & 4 & 8 & 58 & 5 & 72 & 186 \\
\hline 1 & 0.393 & 0.420 & 0.375 & 0.313 & 0.431 & 0.300 & 0.444 & 0.422 \\
\hline 2 & 0.429 & 0.540 & 0.375 & 0.438 & 0.457 & 0.600 & 0.451 & 0.465 \\
\hline 3 & 0.179 & 0.040 & 0.250 & 0.250 & 0.112 & 0.100 & 0.104 & 0.113 \\
\hline \multicolumn{9}{|l|}{$\mathrm{Me}-1$} \\
\hline (n) & 13 & 22 & 3 & 8 & 49 & 4 & 68 & 167 \\
\hline 1 & 0.731 & 0.864 & 0.667 & 0.688 & 0.755 & 0.875 & 0.706 & 0.746 \\
\hline 2 & 0.269 & 0.136 & 0.333 & 0.313 & 0.245 & 0.125 & 0.294 & 0.254 \\
\hline \multicolumn{9}{|l|}{ Lap-1 } \\
\hline (n) & 13 & 23 & 3 & 9 & 57 & 4 & 68 & 177 \\
\hline 1 & 0.500 & 0.500 & 0.500 & 0.500 & 0.474 & 0.125 & 0.507 & 0.486 \\
\hline 2 & 0.500 & 0.500 & 0.500 & 0.500 & 0.526 & 0.875 & 0.493 & 0.514 \\
\hline \multicolumn{9}{|l|}{ Idh-1 } \\
\hline (n) & 14 & 26 & 4 & 9 & 63 & 5 & 77 & 198 \\
\hline 1 & 0.607 & 0.731 & 0.500 & 0.722 & 0.746 & 0.700 & 0.734 & 0.722 \\
\hline 2 & 0.393 & 0.269 & 0.500 & 0.278 & 0.254 & 0.300 & 0.266 & 0.278 \\
\hline
\end{tabular}

(n) - number of accessions analysed per group.

Reis (1996) referred to 56 papers on natural populations of plant species reporting an average number of alleles varying from 1.0 to 4.2. The higher average number of alleles observed in the present work could be credited to the fact that the analyzed systems presented only one polymorphic locus and five systems were monomeric (Acp, G ${ }_{6}$ pdh, Me, Lap and Idh), but only polymorphic loci were evaluated. Lower values could have been observed if monomorphic loci had been included. Little variation was observed among groups for this parameter.

The percentage of polymorphic loci varied from $87.5 \%$ to $100 \%$ among groups. A locus was considered polymorphic when the most common allele frequency did not exceed 0.95. Because this parameter is based on the number of polymorphic loci divided by the total number of loci, and only polymorphic loci were evaluated, it was expected that most groups would show maximum values of polymorphic loci. Only the Bahia group did not present $100 \%$ of polymorphic loci, since this group had the same allele at Acp-1 locus for the four accessions evaluated, behaving as monomorphic for all accessions.

The average heterozigosity $\left(\hat{H}_{0}\right)$ for the accession groups, including the total of accessions, varied from 0.381 for Rondonia to 0.615 for Bahia groups (Table 2). The average heterozigosity obtained by Faraldo (1999) for 23 gardens of cassava from different geographic regions varied from 0.300 to 0.394 . This investigation was carried upon accessions from a germplasm bank, including materials collected from gardens (ethnovarieties), commercial varieties (cultivars) and breeding programs (selected clones, improved cultivars, etc.), which have higher frequency of heterozygote loci, as it would be expected from a highly heterozygous, outcrossing species with vegetative propagation, because of its ability to fix hybrids after the first 
Table 2 - Genetic variability for the groups of cassava accessions and for the total of accessions using eight isozymatic loci.

\begin{tabular}{|c|c|c|c|c|c|}
\hline Group & $\begin{array}{c}\text { Average } \\
\text { sample size }\end{array}$ & $\begin{array}{l}\text { Average number of } \\
\text { alleles per locus }\end{array}$ & $\begin{array}{l}\text { Percentage of } \\
\text { polymorphic loci }{ }^{1}\end{array}$ & $\begin{array}{l}\text { Average observed } \\
\text { heterozigosity }\end{array}$ & $\begin{array}{l}\text { Diversity } \\
\text { Index }\end{array}$ \\
\hline Amazonas & $\begin{array}{c}13.6 \\
(0.2)^{2}\end{array}$ & $\begin{array}{c}2.5 \\
(0.3)\end{array}$ & 100.0 & $\begin{array}{c}0.409 \\
(0.104)\end{array}$ & $\begin{array}{c}0.544 \\
(0.036)\end{array}$ \\
\hline Amapa & $\begin{array}{l}24.4 \\
(0.5)\end{array}$ & $\begin{array}{c}2.5 \\
(0.3)\end{array}$ & 100.0 & $\begin{array}{c}0.436 \\
(0.112)\end{array}$ & $\begin{array}{c}0.479 \\
(0.055)\end{array}$ \\
\hline Bahia & $\begin{array}{l}3.6 \\
(0.2)\end{array}$ & $\begin{array}{c}2.3 \\
(0.2)\end{array}$ & 87.5 & $\begin{array}{c}0.615 \\
(0.149)\end{array}$ & $\begin{array}{c}0.559 \\
(0.087)\end{array}$ \\
\hline Para & $\begin{array}{l}58.8 \\
(1.8)\end{array}$ & $\begin{array}{l}2.5 \\
(0.2)\end{array}$ & 100.0 & $\begin{array}{c}0.408 \\
(0.109)\end{array}$ & $\begin{array}{c}0.507 \\
(0.053)\end{array}$ \\
\hline Rondonia & $\begin{array}{c}4.4 \\
(0.2)\end{array}$ & $\begin{array}{c}2.5 \\
(0.2)\end{array}$ & 100.0 & $\begin{array}{c}0.381 \\
(0.129)\end{array}$ & $\begin{array}{c}0.495 \\
(0.069)\end{array}$ \\
\hline Various & $\begin{array}{c}8.8 \\
(0.2)\end{array}$ & $\begin{array}{c}2.3 \\
(0.2)\end{array}$ & 100.0 & $\begin{array}{c}0.392 \\
(0.092)\end{array}$ & $\begin{array}{c}0.481 \\
(0.055)\end{array}$ \\
\hline $\begin{array}{l}\text { Accessions of } \\
\text { indefinite origin }\end{array}$ & $\begin{array}{l}73.6 \\
(1.5)\end{array}$ & $\begin{array}{c}2.5 \\
(0.3) \\
\end{array}$ & 100.0 & $\begin{array}{c}0.445 \\
(0.115) \\
\end{array}$ & $\begin{array}{c}0.516 \\
(0.042) \\
\end{array}$ \\
\hline Total & $\begin{array}{c}187 \\
(4.1) \\
\end{array}$ & $\begin{array}{c}2.5 \\
(0.3) \\
\end{array}$ & 100.0 & $\begin{array}{c}0.429 \\
(0.109)\end{array}$ & $\begin{array}{c}0.509 \\
(0.046)\end{array}$ \\
\hline
\end{tabular}

${ }^{1}$ The locus is considered polymorphic if the frequency of the most common allele do not exceed 0.95 .

${ }^{2}$ Numbers within brackets refer to the standard deviation.

Table 3 - Estimates of the total genetic diversity $\left(\mathrm{H}_{\mathrm{T}}\right)$, genetic diversity among groups $\left(\mathrm{G}_{\mathrm{ST}}\right)$ and within groups $\left(H_{S}\right)$ in the 200 cassava accessions evaluated.

\begin{tabular}{lccc}
\hline Locus & $\mathrm{G}_{\mathrm{ST}}$ & $\mathrm{H}_{\mathrm{T}}$ & $\mathrm{H}_{\mathrm{S}}$ \\
\hline Acp-1 & 0.061 & 0.325 & 0.305 \\
Gtdh-1 & 0.080 & 0.607 & 0.559 \\
G6pdh-1 & 0.006 & 0.487 & 0.484 \\
Skdh-1 & 0.078 & 0.730 & 0.672 \\
Mdh-1 & 0.021 & 0.611 & 0.597 \\
Me-1 & 0.032 & 0.369 & 0.357 \\
Lap-1 & 0.068 & 0.493 & 0.459 \\
Idh-1 & 0.032 & 0.437 & 0.423 \\
All loci & 0.049 & 0.507 & 0.482 \\
\hline
\end{tabular}

$\left(\mathrm{H}_{\mathrm{T}}\right)$ - total genetic diversity of the species.

$\left(\mathrm{G}_{\mathrm{ST}}\right)$ - proportion of the genetic diversity among populations (groups).

$\left(\mathrm{H}_{\mathrm{S}}\right)$ - diversity component, within populations (groups).

generation of hybridization. Higher heterozigosity would be expected in germplasm banks than in cassava gardens, and this was ascertained in this study. The diversity index varied from 0.479 to 0.559 , and is higher than the average heterozigosity observed for all groups except Bahia, which showed the highest heterozigosity (0.615), possibly because the use of a small number of accessions. Lefèvre \& Charrier (1993b), analyzed 20 isozymatic loci of 365 cassava accessions, and found an expected heterozigosity of 0.225 , small in comparison to Weir's diversity index.

\section{Diversity distribution}

Table 3 presents the estimates of the total genetic diversity $\left(H_{T}\right)$, among $\left(G_{S T}\right)$ and within $\left(H_{S}\right)$ the seven groups of accessions, indicating higher variability within groups than among groups. The $G_{S T}$ values varied from
0.006 to 0.080 , with locus $G_{6}$ pdh-1 showing the lowest value and locus Gtdh-1, the highest. Genetic variability was concentrated within groups, and ranged from 0.305 to 0.672 . The average value of $G_{S T}$ was 0.049 , indicating lower variability among groups and higher variability within groups, averaging 0.482 . These results coincide with the pattern of distribution observed for the allelic frequencies (Table 1). Alleles which had higher frequency in one group also had high frequency in other groups, showing the lowest variation among groups.

Sambatti $(1998,2000)$ reported similar results in cassava gardens, using morphological and isozymatic characters, and found higher variability within gardens than among gardens. Faraldo (1999) also found higher variability within gardens of cassava (0.367) from different geographic regions in Brazil than among gardens (0.165). Mühlen (2000), using DNA markers AFLP, RAPD and microsatellites, studied the genetic diversity of 55 accessions of cassava: 45 from the Amazon region, nine from the South Coast of the State of São Paulo and one representing the commercial cultivar Mantiqueira, and also observed genetic variability higher within groups than among groups.

There is a pattern of distribution similar to what is expected for natural populations of outcrossing plants. Silva (2000) estimated multilocus outcrossing rates varying from $69 \%$ to $100 \%$ in eight ethnovarieties from different origins, including the Mantiqueira cultivar (84\%), confirming that cassava is an outcrossing plant, and explaining the pattern of distribution recorded for the genetic variability.

\section{ACKNOWLEDGEMENTS}

To Drs. Rainério Meireles da Silva and Maria Inês Fernandes Faraldo, for collaborating in this study. To 
Embrapa Amazonia Oriental, for the utilization of the accessions evaluated. To CNPq, for the financial support used in development of this research.

\section{REFERENCES}

ALFENAS, A.C. (ed) Eletroforese de isoenzimas e proteínas afins: fundamentos e aplicações em plantas e microrganismos. Viçosa: UFV, 1998. $574 \mathrm{p}$.

BORSOI FILHO, J.L. Variabilidade isoenzimática e divergência genética de seis cultivares de mandioca (Manihot esculenta Crantz). Viçosa, 1995. 52p. Dissertação (M.S.) - Universidade Federal de Viçosa.

CAMPOS, A.D. Modificações após a colheita no grau de deterioração fisiológica e composição química das raízes de três cultivares de mandioca (Manihot esculenta Crantz). Lavras, 1987. 80p. Dissertação (Mestrado) Escola Superior de Agricultura de Lavras.

CLAYTON, J.; TRETIAK, D. Amine-citrate buffers for $\mathrm{pH}$ control in starch gel electrophoresis. Journal Fisheries Research Board Canadian, v.29, p.1169-1172, 1972.

FARALDO, M.I.F. Distribuição da variabilidade genética e caracterização isoenzimática de etnovariedades em roças de mandioca $(M$. esculenta Crantz) do Brasil. Piracicaba, 1999. 117p. Tese (Doutorado) - Escola Superior de Agricultura "Luiz de Queiroz", Universidade de São Paulo.

FERRAZ, E.M.; GANDARA, F.B.; CUNHA, N.L.; REIS, M.S.; KAGEYAMA, $P . Y$. Eletroforese de isoenzimas para espécies arbóreas: manual de laboratório. Piracicaba: ESALQ, Depto. de Ciências Florestais, Lab. de Biologia Reprodutiva e Genética de Espécies Arbóreas, 1994. 23p.

FUKUDA, W.M.G. Melhoramento da mandioca. In: BORÉM, A. (Ed.) Melhoramento de espécies cultivadas. Viçosa: UFV, 1999. p.410-428.

FUKUDA, W.M.G.; COSTA, I.R.S.; VILARINHOS, A.D.; OLIVEIRA, R.P. Banco de germoplasma de mandioca: manejo, conservação e caracterização. Cruz das Almas: EMBRAPA, CNPMF, 1996. (Documentos, n. 68).

KEPHART, S.R. Starch gel eletrophoresis of plant isozyme: a comparative analysis of techniques. American Journal of Botany, v.77, p.693-712, 1990.

KUMAR, S.; TAMURA, K.; NEI, M. MEGA - Molecular Evolutionary Analysis University Park: Pennsylvania State University, Institute of Molecular Evolutionary Genetics, 1993.

LEFÈVRE, F.; CHARRIER, A. Heredity of seventeen loci in cassava (Manihot esculenta Crantz). Euphytica, v.66, p.171-178, 1993a.

LEFĖVRE, F.; CHARRIER, A. Isozyme diversity within African Manihot germplasm. Euphytica, v.66, p.73-80, 1993b.

MÜHLEN, G.S.; MARTINS,P.S.; ANDO, A. Variabilidade genética de etnovariedades de mandioca, avaliada por marcadores de DNA. Scientia Agricola, v.57, p.319-328, 2000.
NEI, M. Analysis of gene diversity in subdivided populations. Proceedings of the National Academy of Sciences of the United States of America, v.70, p.3321-3323, 1973.

PERONI, N. Taxonomia folk e diversidade intra-específica de mandioca (Manihot esculenta Crantz) em roças de agricultura tradicional em áreas da Mata Atlântica do Sul do Estado de São Paulo. Piracicaba, 1998. 191p. Dissertação (Mestrado) - Escola Superior de Agricultura "Luiz de Queiroz", Universidade de São Paulo.

REIS, M.S. Distribuição e dinâmica da variabilidade genética em populações naturais de palmiteiro (Euterpe edulis Martius). Piracicaba, 1996. 210p Tese (Doutorado) - Escola Superior de Agricultura "Luiz de Queiroz", Universidade de São Paulo.

SAMBATTI, J.B.M. Erosão genética e conservação de germoplasma de mandioca na agricultura autóctone em Ubatuba - SP. Piracicaba, 1998. 165p. Dissertação (Mestrado) - Escola Superior de Agricultura "Luiz de Queiroz", Universidade de São Paulo.

SAMBATTI, J.B.M.; MARTINS,P.S.; ANDO, A. Distribuição da diversidade isoenzimática e morfológica da mandioca na agricultura autóctone de Ubatuba. Scientia Agricola, v.57, p.75-80, 2000.

SCANDALIOS, J.G. Genetic control of multiple molecular forms of enzymes in plants. Biochemical Genetics, v.3, p.37-79, 1969.

SILVA, R.M. Sistema reprodutivo, fluxo gênico e paternidade em roças de etnovariedades de mandioca (Manihot esculenta Crantz). Piracicaba, 2000. $131 \mathrm{p}$. Tese (Doutorado) - Escola Superior de Agricultura "Luiz de Queiroz", Universidade de São Paulo.

SOLTIS, D.E.; HAUFLER, C.H.; DARROW, D.C.; GASTONY, G.J. Starch gel electrophoresis of ferns: a compilation of grinding buffers, gel and electrode buffers, and staining schedules. American Fern Journal, v.73, p.9-26, 1983.

SWOFFORD, D.L.; SELANDER, R.B. Biosys-1: a FORTRAN program for the comprehensive analysis for electrophoresis data in population genetics and systematics. Journal of Heredity, v.38, p.1358-1370, 1991.

VAN SLOTEN, D.H. The role of curators, breeders and other users of germplasm in characterization and evaluation of crop genetic resources. IBPGR/SEAN, p.3-8, 1987. Special issue.

WEIR, B.S. Genetic data analysis II: methods for discrete population genetic data. 2.ed. Sunderland: Sinaver Associates, 1996. 445p.

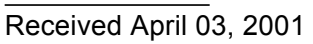

